\title{
Molecular diagnosis of American Cutaneous Leishmaniasis (ACL) in dogs from an endemic area in Pernambuco State, Brazil
}

\author{
[Diagnóstico Molecular da Leishmaniose Tegumentar Americana (LTA) em cães de área endêmica \\ no estado de Pernambuco, Brasil]
}

\section{"Artigo Científico/Scientific Article"}

\author{
Jussara Valença Alencar Ramos ${ }^{1}$, Juliana Públia Cordeiro Tavares ${ }^{2}$, Silvia Rafaelli Marques ${ }^{1}$, \\ Ivanise Maria Santana ${ }^{1}$, Thiago André Santos Andrade ${ }^{1}$, Jaciara Araújo Santana ${ }^{3}$, \\ Neurisvan Ramos Guerra ${ }^{1}$, Rafael Antonio Nascimento Ramos ${ }^{4}$, Milena Paiva Cavalcanti ${ }^{5}$, \\ Leucio Câmara Alves ${ }^{1}$, Edenilze Teles Romeiro ${ }^{1}$, Maria Aparecida Gloria Faustino ${ }^{1 *}$
}

\footnotetext{
${ }^{1}$ Department of Veterinary Medicine, Federal Rural University of Pernambuco, Recife-PE, Brazil.

${ }^{2}$ Autonomous Veterinarian, Recife-PE, Brazil.

${ }^{3}$ Municipal Health Secretary, Igarassu-PE, Brazil.

${ }^{4}$ Academic Unit of Garanhuns, Federal Rural University of Pernambuco, Garanhuns-PE, Brazil.

${ }^{5}$ Department of Immunology, Centro de Pesquisa Aggeu Magalhães, Fundação Oswaldo Cruz, Recife-PE, Brazil.

*Autor para correspondência/Corresponding author: E-mail: magfaustino@ hotmail.com
}

\begin{abstract}
A survey was carried out to detect American cutaneous leishmaniasis (ACL) among dogs in an area where a human outbreak had occurred in the state of Pernambuco, in northeastern Brazil. Domiciled dogs living in the district of Três Ladeiras, Igarassu were used in the present study. The following procedures were performed: The Polymerase Chain Reaction (PCR) $(n=126)$; the Immunofluorescence Antibody Test (IFAT) ( $n=80)$; and a parasitological examination to detect amastigote forms of Leishmania sp. in skin lesions $(\mathrm{n}=43)$. Associations between the infection in animals and the clinical and epidemiological factors were analyzed using Fisher's exact test or the Pearson's chi-squared test. In total, 46.8\% (59/126) of the samples tested were PCRpositive. Although a higher frequency of positivity was detected among males (46.3 \%) and animals aged between 3 and 4 years $(50.0 \%)$, no significant associations were recorded for these variables $(\mathrm{p}>0.05)$. Similarly, the clinical signs and aspects related to the environment in which the animal lives did not differ significantly, but differences were recorded for the variable locality. In the IFAT, only $6.2 \%(5 / 80)$ of the dogs were positive and no amastigote forms of Leishmania sp. were detected.
\end{abstract}

Keywords: Leishmania braziliensis; PCR; diagnosis; Canis familiaris.

\begin{abstract}
Resumo
Objetivou-se neste trabalho identificar casos positivos de Leishmaniose Tegumentar Americana em cães em uma área de ocorrência de surto humano. Os seguintes procedimentos foram realizados: Reação em Cadeia da Polimerase (PCR) $(\mathrm{n}=126)$; Reação de Imunofluorescência Indireta (RIFI) (n = 80); e exame parasitológico para detecção de formas amastigotas de Leishmania sp. em lesões de pele $(n=43)$. Associações entre a infecção em animais e os fatores clínicos e epidemiológicos foram analisadas pelo teste exato de Fisher ou pelo teste qui-quadrado de Pearson. No total, 46,8\% (59/126) das amostras testadas foram PCR-positivas. Embora tenha sido detectada maior frequência de positividade entre o sexo masculino (46,3\%) e animais com idade entre 3 e 4 anos $(50,0 \%)$, não foram registradas associações significativas para essas variáveis $(\mathrm{p}>0,05)$. Da mesma forma, os sinais e aspectos clínicos relacionados ao ambiente em que o animal vive não diferiram significativamente, mas foram registradas diferenças para a variável localidade. Na RIFI apenas 6,2\% (5/80) dos cães foram positivos e nenhuma forma amastigota de Leishmania sp. foi detectada.
\end{abstract}

Palavras-chave: Leishmania braziliensis; PCR; diagnóstico; Canis familiaris. 


\section{Introduction}

The epidemiological role of domestic animals in the cycle of American cutaneous leishmaniasis (ACL) was reported a century ago when the infection was detected among dogs in the state of São Paulo, Brazil (Brumpt and Pedroso, 1913). However, as for other domestic animals, there is no scientific evidence to support the role of dogs as reservoirs of Leishmania species, being considered accidental hosts of the ACL (DantasTorres, 2007; BRASIL, 2017).

Little information on the infection in these animals has been reported in recent years. A simultaneous outbreak of canine and human ACL was reported in Colombia (Vélez et al., 2012). In the Southeast of Brazil, previous studies have demonstrated the presence of infected dogs in endemic areas of the human form of the disease (Dias et al., 1977; Barreto et al., 1984; Coutinho et al., 1985). In Southern Brazil, 13.9\% (57/410) of serological samples reacted with the Leishmania braziliensis antigen on ELISA test in dogs from the State of Paraná (Castro et al., 2007). More recently studies in dogs reported a seroprevalence of $8.7 \%$ in the municipality of Balneário Camboriú, in the state of Santa Catarina (Júnior et al., 2010), 8.2\% in rural settlements in northern Paraná State (SilvaFilho, 2012).

In Huanuco, Peru, the large number of dogs and the presence of dogs in residences were considered risk factors for the occurrence of ACL (Reithinger et al., 2003). The same authors suggested that dogs play an important role in the peridomestic transmission of ACL to human beings as confirmed by Membrive et al. (2012). Recently, evidences that dogs can possibly act as reservoir of L. (V.) braziliensis were reported in study performed in an endemic rural area in northern Paraná State - Brazil (Marquez et al., 2017), however, no correlation or association between human and canine seroprevalences was recorded in another study in Londrina - PR (Benitez et al., 2018).

PCR has been widely used to diagnose ACL and has been shown to be the best method, especially when compared with parasitological techniques (Reithinger and Davies, 2002; Andrade et al., 2005; Dantas-Torres et al., 2010; Santaella et al., 2011).
Therefore, the aim of the present study was to detect the DNA of Leishmania sp. among dogs living in an endemic area (state of Pernambuco, Northeast of Brazil) where a human outbreak had occurred. In addition, associations between positivity and clinical and epidemiological factors related to the dogs were also analyzed.

\section{Material and Methods \\ Study area}

The present study was conducted in the municipality of Igarassu (7'50'00' S; 34 $54^{\circ} 30^{\prime}$ ' W), endemic to ACL (Andrade et al., 2012; Silva et al., 2017), which belongs to the Metropolitan Region of Recife. This area lies 19 meters above sea level and occupies a total area of about 306 $\mathrm{km}^{2}$, with rural and urban areas of $60 \mathrm{~km}^{2}$ and 246 $\mathrm{km}^{2}$, respectively. Igarassu is $34.9 \mathrm{~km}$ from the Recife, capital of Pernambuco state.

The specific study area was the district of Três Ladeiras, a region in which the human and canine populations are estimated at 1,507 and 177, respectively (IDB, 2008 ${ }^{1}$ ). This area was selected based on current data for human cases of ACL, including the localities Vila Jarapiá, Rua Santa Cruz, Sítio Tambô, Fazenda Três Ladeiras, Carpinteiro José Grande and Loteamento Bela Vista (Table 1). An outbreak was reported between the years of 2008 and 2010, data provided by the Epidemiological Surveillance municipality of Igarassu. In addition, vectors of ACL have been detected inside houses and in the peridomiciles of the study area (Lucena et al., 1984).

\section{Sampling collection}

Domiciled dogs $(n=126)$ of both sexes, mixed breeds and different ages were selected through non-probability sampling for inclusion in the present study.

Dogs were surveyed by house-to-house visits. Owners signed the Informed Consent Form (ICF). A form containing information about the identification, sex, breed, age, evolution of clinical status of the animals, and presence of the vector was filled. The animals were then physically restrained and examined for the presence of cutaneous lesions. Their nutritional condition was determined by the researcher observation based on visual, palpable or both characterisitics that allows

\footnotetext{
${ }^{1}$ Basic Health Data Indices - Brazil (2008)
} 
to judge the animal's silhouette examining the amount of subcutaneous fat and superficial musculature (Burkholder, 2000). Besides that sampling collection was also performed (blood and skin).

Blood samples $(2-5 \mathrm{~mL})$ were collected by venipuncture of the cephalic vein. The sample was divided into two aliquots and then stored in plastic sterile tubes (with and without anticoagulant EDTA). Samples were placed in an isothermal box and taken to the laboratory. All samples were stored at $-80^{\circ} \mathrm{C}$ until the molecular processing (DNA extraction and PCR). Sera samples were kept at $-20^{\circ} \mathrm{C}$ for subsequent serological analysis (IFAT).

Samples for parasitological examination were obtained from cutaneous lesions on dogs by scarifying the lesion border and imprinting on glass slides. The slides were then air-dried and taken to the laboratory for subsequent analysis.

\section{Molecular Analysis}

The genomic DNA was extracted from blood samples using a commercial kit (Illustra ${ }^{\mathrm{TM}}$ blood genomicprep mini spin Kit GE Healthcare, New York, USA), following the manufacturer's instructions.

The detection of $L$. braziliensis DNA was performed using conventional PCR and the following primers: B1 (5'-GGG TTG GGT GTA ATA TGG TAG-3 ') and B2 (5'-ATT CTA GTG CAC GGG GGA GG-3') (Bruijn and Barker, 1992). These primers amplify a fragment of 750 base pairs (bp) of kinetoplast DNA (kDNA) (Martins et al., 2010).

The amplification reactions were performed in an automatic thermocycler (Mastercycler Gradient, Eppendorf, Hamburg, Germany), based on the following run protocol: initial denaturation (five minutes at $94^{\circ} \mathrm{C}$ ); followed by 35 cycles (denaturation: 30 seconds at $94^{\circ} \mathrm{C}$, annealing: one minute at $67^{\circ} \mathrm{C}$; extension: 30 seconds at $72^{\circ} \mathrm{C}$ ), and a final extension (five minutes at $72^{\circ} \mathrm{C}$ ). Amplicons $(10 \mu \mathrm{l})$ were electrophoresed on $1.5 \%$ agarose gel, stained with ethidium bromide, and then viewed through a transilluminator. Positive (MHOM / BR /1975 / M2903) and negative controls (ultra-pure water) were used in all reactions.

\section{Serological Analysis}

The Immunofluorescence Antibody Test
(IFAT) was performed using a commercial kit (IFAT - American Cutaneous Leishmaniasis, BioManguinhos / FIOCRUZ). The antigen was prepared from promastigote forms of $L$. (V.) braziliensis (provided by BioManguinhos/Fundação Oswaldo Cruz, RJ). The conjugates were used at a dilution of 1:40, following the manufacturer's instructions.

\section{Parasitological diagnosis}

The material obtained from the cutaneous lesions was fixed and stained using the Panótico rápido kit. Afterwards, the material was analyzed under an optical microscope to determine the presence of amastigote forms of Leishmania sp.

\section{Statistical analysis}

Associations between the PCR results and variables such as sex, age and clinical and environment factors were analyzed through Fisher's exact test or the chi-squared test, together with SPSS statistical software (Statistical Package for the Social Sciences), with the significance level set at $\mathrm{p}<0.05$.

\section{Results}

Of the 126 blood samples analyzed in the PCR, $46.8 \%$ were positive (59/126) for the DNA of L. braziliensis. Although a higher frequency of positivity was observed in dogs aged from three to four years old $(50.0 \%)$ and dogs aged up to two years old $(36.4 \%)$, as well as for males $(46.3 \%)$, no significant differences $(\mathrm{p}>0.05)$ were detected between the results and the variables age and sex (Table 1). On the other hand, when the locality was analyzed, higher percentages of positive animals were detected in the Fazenda Três Ladeiras and Vila Jarapiá followed by Rua Santa Cruz, Loteamento Bela Vista and Carpinteiro José Grande (Table 1).

No significant associations were found between the clinical parameters and the PCR results (Table 2). It is important to note that of the 59 positive dogs, $88.1 \%(52 / 59)$ exhibited satisfactory or optimum, and only $42.4 \%(25 / 59)$ exhibited lesions suggestive of ACL, such as

Alopecia, Onychogryphossis, Weight Loss and Injury cutaneous, although considering the total of these $58.1 \%(25 / 43)$ had been positive (Table 2). 
Table 1. Absolute (n) and relative frequency (\%) of blood samples analyzed in the PCR to detect L. braziliensis kDNA in dogs according to age, sex, locality and origin.

\begin{tabular}{|c|c|c|c|c|c|c|c|c|}
\hline \multirow{3}{*}{$\frac{\text { Variable }}{\text { Age } \text { (vears) }^{(1)}}$} & \multicolumn{6}{|c|}{ PCR } & \multirow{3}{*}{$\mathbf{p}$} & \multirow{3}{*}{ OR (CI 95\%) } \\
\hline & \multicolumn{2}{|c|}{ Positive } & \multicolumn{2}{|c|}{ Negative } & \multicolumn{2}{|c|}{ TOTAL } & & \\
\hline & $\mathrm{n}$ & $\%$ & $\mathrm{n}$ & $\%$ & $\mathrm{n}$ & $\%$ & & \\
\hline Up to 2 & 12 & 36.4 & 21 & 63.6 & 33 & 100.0 & $\mathrm{p}^{(2)}=0.129$ & $1.71(0.54-5.50)$ \\
\hline From 3 to 4 & 20 & 50.0 & 20 & 50.0 & 40 & 100.0 & & $3.00(0.99-9.13)$ \\
\hline More than 5 & 6 & 25.0 & 18 & 75.0 & 24 & 100.0 & & 1.00 \\
\hline Total & 38 & 39.2 & 59 & 60.8 & 97 & 100.0 & & \\
\hline \multicolumn{9}{|l|}{ Sex } \\
\hline Male & 37 & 46.3 & 43 & 53.8 & 80 & 100.0 & $\mathrm{p}^{(2)}=0.864$ & 1.00 \\
\hline Female & 22 & 47.8 & 24 & 52.2 & 46 & 100.0 & & $1.07(0.52-2.20)$ \\
\hline Total & 59 & 46.8 & 67 & 53.2 & 126 & 100.0 & & \\
\hline \multicolumn{9}{|l|}{ Locality } \\
\hline Vila Jarapiá & 28 & 58.3 & 20 & 41.7 & 48 & 100.0 & $\mathrm{p}^{(3)}=0.0048^{*}$ & $* *$ \\
\hline Rua Santa Cruz & 19 & 39.6 & 29 & 60.4 & 48 & 100.0 & & $* *$ \\
\hline Sítio Tambô & - & - & 2 & 100.0 & 2 & 100.0 & & $* *$ \\
\hline Fazenda Três Ladeiras & 6 & 100.0 & - & - & 6 & 100.0 & & $* *$ \\
\hline Carpinteiro José Grande & 1 & 16.7 & 5 & 83.3 & 6 & 100.0 & & $* *$ \\
\hline Loteamento Bela Vista & 5 & 31.3 & 11 & 68.8 & 16 & 100.0 & & $* *$ \\
\hline Total & 59 & 46.8 & 67 & 53.2 & 126 & 100.0 & & \\
\hline
\end{tabular}

(*): Significance level set at $\mathrm{p}<0.05$ (**): Values not determined due to null or low frequencies.

$\begin{array}{llll}\text { (1): For } 29 \text { animals the information about age was not provided. (2): Pearson's chi-squared test } & \text { (3): Fisher's exact test }\end{array}$

Table 2. Absolute (n) and relative frequency (\%) of blood samples analyzed in the PCR to detect L. braziliensis kDNA in dogs according to clinical aspects.

\begin{tabular}{|c|c|c|c|c|c|c|c|c|}
\hline \multirow{3}{*}{$\frac{\text { Variable }}{\text { Nutritional condition }}$} & \multicolumn{6}{|c|}{ PCR } & \multirow{3}{*}{ p } & \multirow{3}{*}{ OR (CI 95\%) } \\
\hline & \multicolumn{2}{|c|}{ Positive } & \multicolumn{2}{|c|}{ Negative } & \multicolumn{2}{|c|}{ TOTAL } & & \\
\hline & $\mathrm{n}$ & $\%$ & $\mathrm{n}$ & $\%$ & $\mathrm{n}$ & $\%$ & & \\
\hline Optimum/Satisfactory & 52 & 49.1 & 54 & 50.9 & 106 & 100.0 & $\mathrm{p}^{(1)}=0.248$ & $1.79(0.66-4.84)$ \\
\hline Regular/ Poor & 7 & 35.0 & 13 & 65.0 & 20 & 100.0 & & 1.00 \\
\hline Total & 59 & 46.8 & 67 & 53.2 & 126 & 100.0 & & \\
\hline \multicolumn{9}{|l|}{ Alopecia } \\
\hline Yes & 14 & 46.7 & 16 & 53.3 & 30 & 100.0 & $\mathrm{p}^{(1)}=0.984$ & 1.00 \\
\hline No & 45 & 46.9 & 51 & 53.1 & 96 & 100.0 & & $1.01(0.44-2.29)$ \\
\hline Total & 59 & 46.8 & 67 & 53.2 & 126 & 100.0 & & \\
\hline \multicolumn{9}{|l|}{ Onychogryphosis } \\
\hline Yes & 5 & 71.4 & 2 & 28.6 & 7 & 100.0 & $\mathrm{p}^{(2)}=0.251$ & $* *$ \\
\hline No & 54 & 45.4 & 65 & 54.6 & 119 & 100.0 & & \\
\hline Total & 59 & 46.8 & 67 & 53.2 & 126 & 100.0 & & \\
\hline \multicolumn{9}{|l|}{ Weight Loss } \\
\hline Yes & 3 & 60.0 & 2 & 40.0 & 5 & 100.0 & $\mathrm{p}^{(2)}=0.664$ & $* *$ \\
\hline No & 56 & 46.3 & 65 & 53.7 & 121 & 100.0 & & \\
\hline Total & 59 & 46.8 & 67 & 53.2 & 126 & 100.0 & & \\
\hline \multicolumn{9}{|l|}{ Cutaneous lesion } \\
\hline Yes & 25 & 58.1 & 18 & 41.9 & 43 & 100.0 & $\mathrm{p}^{(1)}=0.067$ & $2.00(0.95-4.23)$ \\
\hline No & 34 & 41.0 & 49 & 59.0 & 83 & 100.0 & & 1.00 \\
\hline Total & 59 & 46.8 & 67 & 53.2 & 126 & 100.0 & & \\
\hline
\end{tabular}

Table 3 displays the results according to the characteristics of the environment in which the animals live. In the PCR, a high frequency of positivity $(47.1 \%)$ was observed among animals who lived on properties where the owners reported the presence of mosquitoes, with a high frequency $(46.3 \%)$. In addition, mosquitoes were observed during the night $(47.2 \%)$ and in houses in areas with secondary vegetation $(44.9 \%)$. This information was provided by the owners and not by direct observation of the insect specimens.
Therefore, we cannot confirm that these specimens are vectors of ACL.

Of the 126 blood samples collected, $63.5 \%$ (80/126) were analyzed by IFAT and $6.2 \%(5 / 80)$ of them were positive for ACL. Of the animals studied herein, $34.1 \%$ (43/126) exhibited cutaneous lesions. However, in the parasitological examination, all samples were negative for the presence of amastigote forms of Leishmania sp. (Table 2). Among the animals with cutaneous lesions, $58.1 \%(25 / 43)$ were positive in the molecular examination. 
Table 3. Absolute (n) and relative frequency (\%) of blood samples analyzed in the PCR to detect L. braziliensis kDNA in dogs according to the environment in which the animals live.

\begin{tabular}{|c|c|c|c|c|c|c|c|c|}
\hline \multirow{3}{*}{$\begin{array}{c}\text { Variable } \\
\text { Presence of mosquitões }\end{array}$} & \multicolumn{6}{|c|}{ PCR } & \multirow{3}{*}{$\mathbf{p}$} & \multirow{3}{*}{ OR (CI 95\%) } \\
\hline & \multicolumn{2}{|c|}{ Positive } & \multicolumn{2}{|c|}{ Negative } & \multicolumn{2}{|c|}{ TOTAL } & & \\
\hline & $\mathrm{n}$ & $\%$ & $\mathrm{n}$ & $\%$ & $\mathrm{n}$ & $\%$ & & \\
\hline Yes & 57 & 47.1 & 64 & 52.9 & 121 & 100.0 & $\mathrm{p}(1)=1.000$ & ** \\
\hline No & 2 & 40.0 & 3 & 60.0 & 5 & 100.0 & & \\
\hline Total & 59 & 46.8 & 67 & 53.2 & 126 & 100.0 & & \\
\hline \multicolumn{9}{|l|}{$\begin{array}{c}\text { Frequency of presence of } \\
\text { mosquitoes }\end{array}$} \\
\hline High & 25 & 46.3 & 29 & 53.7 & 54 & 100.0 & $\mathrm{p}(2)=0.289$ & 1.00 \\
\hline Moderate & 14 & 38.9 & 22 & 61.1 & 36 & 100.0 & & $0.74(0.31-1.74)$ \\
\hline Low & 18 & 58.1 & 13 & 41.9 & 31 & 100.0 & & $1.61(0.66-3.92)$ \\
\hline $\begin{array}{c}\text { Total } \\
\end{array}$ & 57 & 47.1 & 64 & 52.9 & 121 & 100.0 & & \\
\hline \multicolumn{9}{|c|}{$\begin{array}{c}\text { Period in which specimens were } \\
\text { detected }\end{array}$} \\
\hline Morning & 8 & 47.1 & 9 & 52.9 & 17 & 100.0 & $\mathrm{p}(2)=0.999$ & 1.00 \\
\hline Afternoon & 15 & 46.9 & 17 & 53.1 & 32 & 100.0 & & $0.99(0.31-3.23)$ \\
\hline Night & 34 & 47.2 & 38 & 52.8 & 72 & 100.0 & & $1.01(0.35-2.90)$ \\
\hline Total & 57 & 47.1 & 64 & 52.9 & 121 & 100.0 & & \\
\hline \multicolumn{9}{|l|}{ Presence of Vegetation } \\
\hline Primary & 28 & 49.1 & 29 & 50.9 & 57 & 100.0 & $\mathrm{p}(2)=0.639$ & $1.18(0.59-2.39)$ \\
\hline Secondary & 31 & 44.9 & 38 & 55.1 & 69 & 100.0 & & 1.00 \\
\hline Total & 59 & 46.8 & 67 & 53.2 & 126 & 100.0 & & \\
\hline
\end{tabular}

\section{Discussion}

This high rate of prevalence corroborates the findings of Reithinger and Davies (2002), who detected a high prevalence of Leishmania braziliensis and Leishmania peruviana among dogs living in an endemic area of Peru using the same molecular test. In the municipality of Mariluz in the Brazilian state of Paraná, Velasquez et al. (2006) detected positivity rates of $26.3 \%$ (10/38) and $15.8 \%(16 / 101)$ in dogs with and without cutaneous lesions suggestive of ACL, respectively. In the Brazilian state of Pernambuco, municipality of São Vicente Férrer, 20 out of 41 dogs analyzed were positive in the PCR (Dantas-Torres et al., 2010).

In the present study, the variable related to the age of the dogs was impaired by the fact that most of their owners did not know the exact age of the animal, however the present data corroborates with previous studies. For example, França-Silva et al. (2003), in an endemic region of Minas Gerais, and Santaella et al. (2011) in Chaparral County, Colombia, where outbreaks of human leishmaniasis had occurred. Júnior et al. (2010) studied ACL in 275 dogs living in an endemic area in the municipality of Balneário Camboriú (Brazil) and reported that the age of the dogs did not significantly influence the prevalence of infection.

Dogs that were infected by the parasite but exhibited no lesions have been frequently found in endemic areas (Madeira et al., 2000; Santos et al., 2005), suggesting that the presence of asymptomatic dogs for ACL does not indicate the absence of the infection (Barbosa et al., 1999).

Related to the seroprevalence, the results are higher than the $5.8 \%$ reported by Júnior et al. (2010) in an endemic area of the municipality of Balneário Camboriú, in the Brazilian state of Santa Catarina. Higher rates of infection have been reported in the following regions of Brazil: Maricá, Rio de Janeiro (33.3 \%; 2/6) (Madeira et al., 2003); suburban $(8.9 \%)$ and rural areas $(39.4 \%)$ of the state of Rio de Janeiro (Santos et al., 2005); and the state of Paraná (44 \% - Castro et al., 2005), (47.2 $\%$ - Zanzarini et al., 2005) and (16.8\% - Velasquez et al., 2006).

Although all of the studies described above reported higher seroprevalence rates than the present study $(6.2 \%)$, the value obtained herein is considered relevant. According to Leontides et al. (2002) and Reithinger et al. (2003), failures in the detection of infected animals during the pre-patent period and before seroconversion are common in serological tests, particularly when considering that this phenomenon may occur months after infection. In addition, positive animals can show up as negative in the serology, which could cause the seroprevalence to be underestimated in epidemiological studies. According to Mendonça et al. (1998), different results in the IFAT can 
occur, most likely due to the reduced antigenicity of the parasite or the low levels of antibodies.

In the present study, five animals were simultaneously positive in the IFAT and the PCR. A previous study detected IgG antibodies against L. panamensis by IFAT however all blood samples were PCR negative for Leishmania spp. DNA (Calzada et al., 2015).

The results about cutaneous lesion examination are different from those reported by Viana in the Brazilian state of Espírito Santo, where $67.3 \%(31 / 46)$ of the animals with cutaneous lesions were positive in the parasitological examination (Falqueto et al., 1986). Similarly, in the municipality of Maricá in the state of Rio de Janeiro, $75 \%$ of the dogs with lesions suggestive of ACL (6/8) were confirmed positive in the skin biopsy (Madeira et al., 2003). In Mariluz in the Brazilian state of Paraná, $12.8 \%$ of the dogs with lesions suggestive of ACL (5/39) were positive in the biopsy and/or scarification of the lesion (Velasquez et al., 2006).

The dogs that exhibited lesions and were negative in the parasitological examination were probably infected a long time ago, since it is known that the probability of retrieving the parasite from the lesion is inversely proportional to the age of the lesion (Marco et al., 2001). This hypothesis corroborates the results of Velasquez et al. (2006), who stated that Leishmania parasites belonging to the subgenus Viannia initially colonize the lesion, before migrating to the blood stream when the infection evolves. Ferrer (1999) and Laurenti (2009) stated that, despite the $100 \%$ specificity provided by this technique, sensitivity depends on the level of parasitism, which may explain the negative results obtained in the present study.

It is important to highlight the relevance of the use of PCR in the diagnosis of ACL among dogs living in an endemic area, when compared with the other methods used herein (IFAT and direct examination). The PCR was able to detect a higher number of positive animals, thereby increasing the accuracy of the diagnosis as observed on human cases (Brito et al, 2012). In addition, the hematogenous dissemination of the causative agent of ACL seems to be a common event, which is significant in the epidemiological analysis.

\section{Conclusion}

In conclusion, the present study confirms the presence of dogs that are positive for ACL in the district of Três Ladeiras and demonstrated that the PCR of peripheral blood is an effective method of detecting L. braziliensis kDNA among dogs living in an endemic area.

The authors declare that there is no conflict of interest.

\section{Conflict of Interest}

The authors declare no conflict of interest.

\section{Ethics Committee}

All procedures performed herein were approved by the Ethical Committee for the Use of Animals (CEUA / UFRPE; license number: 022/2010) and by the Research Ethics Committee of the Oswaldo Cruz Foundation (CEP-FIOCRUZ / PE, 09/2011).

\section{References}

Andrade, B.B.; Boaventura, V.; Barral-Netto, M.; Barral, A. Métodos Diagnósticos da Leishmaniose Tegumentar: Fatos, Falácias e Perspectivas. Gazeta Médica da Bahia, 75:75-82, 2005.

Andrade, T.A.S.; Soares, F.C.S.; Ramos, J.V.A.; Faustino, M.A.G. Epidemiologic profile of notified cases of American Tegumentary Leishmaniasis in the town of Igarassu, Pernambuco (Brazil), in the period of 2008 to 2010. Scire Salutis, 2(2):5-15, 2012.

Barbosa, G.M.S.; Marzochi, M.C.A.; Massard, C.L.; Lima, G.P.S.; Confort, E.M. Aspectos epidemiológicos da leishmaniose tegumentar americana em cães, no Município de Paraty, Estado do Rio de Janeiro Brasil. Cadernos de Saúde Pública, 15:641-646, 1999.

Barreto, A.C.; Cuba, C.C.; Vexenat, J.A.; Rosa, A.C.; Marsden, P.D.; Magalhães, A.V. Características epidemiológicas da leishmaniose tegumentar americana em uma região endêmica do Estado da Bahia, II. Leishmaniose canina. Revista da Sociedade Brasileira de Medicina Tropical, 17:59-65, 1984.

Benitez, A.N.; Martins, F.D.C.; Mareze, M.; Nino, B.S.L.; Caldart, E.T.; Ferreira, F.P.; MitsukaBreganó, R; Freire, R.L.; Galhardo, J.A.; Martins, C.M.; Biondo, A.W.; Navarro, I.T. Spatial and simultaneous seroepidemiology of anti-Leishmania spp. antibodies in dog owners and their dogs from randomly selected households in a major city of southern Brazil. 
Preventive Veterinary Medicine, 154: 4753, 2018.

Brasil. Ministério da Saúde. Secretaria de Vigilância em Saúde. Departamento de Vigilância das Doenças Transmissíveis. Manual de vigilância da leishmaniose tegumentar [recurso eletrônico] / Ministério da Saúde, Secretaria de Vigilância em Saúde, Departamento de Vigilância das Doenças Transmissíveis. - Brasília: Ministério da Saúde, 2017. 189 p.

Brito, M.E.F.; Andrade, M.S.; Dantas-Torres, F.; Rodrigues, E.H.G.; Paiva-Cavalcanti, M.; Almeida, A.M.P.; Brandão-Filho, S. Critical appraisal of cutaneous leishmaniasis in northeastern Brazil. Revista da Sociedade Brasileira de Medicina Tropical, 45(4):425429, 2012.

Bruijn, M.H.L.; Barker, D.C. Diagnosis of New World leishmaniasis: Specific detection of species of the Leishmania braziliensis complex by amplification of kinetoplast DNA. Acta Tropical, 52:45-58, 1992.

Brumpt, E.; Pedroso, A. Pesquisas epidemiológicas sobre a leishmaniose americana das florestas no estado de São Paulo. Anais Paulistas de Medicina e Cirurgia, 1:97-136, 1913.

Burkholder, W. J. Use of body condition scores in clinical assessment of the provision of optimal nutrition. Journal of the American Veterinary Medical Association, 217(5):650-654, 2000.

Calzada, J.E.; Saldaña, A.; González, K.; Rigg, C.; Pineda, V.; Santamaría, A.M.; Rodríguez, I.; Gottdenker, N.L.; Laurenti, M.D.; Chaves, L.F. Cutaneous Leishmaniasis in dogs: is high seroprevalence indicative of a reservoir role? Parasitology, 142(9):1202-1214, 2015.

Castro, E.A.; Luz, E.; Telles, F.Q.; Pandey, A.; Biseto, A.; Dinaiski, M.; Sbalqueiro, I.; Soccol, V.T. Eco-epidemiological survey of Leishmania (Viannia) braziliensis American cutaneous and mucocutaneous leishmaniasis in Ribeira Valley River, Paraná State, Brazil. Acta Tropical, 93:141-149, 2005.

Castro, E.A; Thomaz-Soccol, V.; Augur, C.; Luz, E. Leishmania (Viannia) braziliensis: Canine epidemiology of tegumentary leishmaniasis in the state of Paraná (Brazil). Experimental Parasitology, 117 13-21. (2007).

Coutinho, S.G.; Nunes, M.P.; Marzoch, M.C.A.; Tramontano, N. A survey for american cutaneous and visceral leishmaniasis among 1342 dogs from areas in Rio de Janeiro (Brazil) where the human diseases occur. Memórias do Instituto Oswaldo Cruz, 80:17-22, 1985.

Dantas-Torres, F. The role of dogs as reservoirs of Leishmania parasites, with emphasis on Leishmania (Leishmania) infantum and Leishmania (Viannia) braziliensis. Veterinary Parasitology, 149:139-146, 2007.

Dantas-Torres, F.; Cavalcanti, M.P.; Figueredo, L.A.; Melo, M.F.; da Silva, F.J.; da Silva, A.L.; Almeida, E.L.; Brandão-Filho, S.P. Cutaneous and visceral leishmaniosis in dogs from a rural community in northeastern Brazil. Veterinary Parasitology, 170:313317, 2010.

Dias, M.; Mayrink, W.; Deane, L.M.; da Costa, C.A.; Magalhães, P.A.; Melo, M.N.; Batista, S.M.; Araujo, F.G.; Coelho, M.V.; Williams, P. Epidemiologia da leishmaniose tegumentar americana. I. Estudo de reservatórios em área endêmica no Estado de Minas Gerais. Revista do Instituto de Medicina Tropical de São Paulo, 19:403-410, 1977.

Falqueto, A.; Coura, J.R.; Barros, G.C.; Grimaldi Filho, G.; Sessa, P.A.; Carias, V.R.; dé Jesus, A.C.; de Alencar, J.T. Participação do cão no ciclo de transmissão da Leishmaniose tegumentar no Município de Viana, estado do Espírito Santo, Brasil. Memórias do Instituto Oswaldo Cruz, 81:155-163, 1986.

França-Silva, J.C.; Costa, R.T.; Siqueira, A.M.; Machado-Coelho, G.L.; da Costa, C.A.; Mayrink, W.; Vieira, E.P.; Cost, J.S.; Genaro, O.; Nascimento, E. Epidemiology of canine visceral leishmaniosis in the endemic area of Montes Claros Municipality, Minas Gerais State, Brazil. Veterinary Parasitology, 111:161-173, 2003.

Júnior, A.H.; Bellato, V.; Souza, A.P.; Moura, A.B.; Sartor, A.A.; Santos, E.G.O.B.; Silva, V.L. Leishmaniose tegumentar canina no município de Balneário Camboriú, Estado de Santa Catarina. Revista da Sociedade Brasileira de Medicina Tropical de São Paulo, 43:713-718, 2010.

Laurenti, M.D. Correlação entre o diagnóstico parasitológico e sorológico na leishmaniose visceral americana canina. BEPA, 67:13-23, 2009. 
Leontides, S.L.; Saridomichelakis, M.N.; Billinis, C.; Kontos, V.; Koutinas, A.F.; Galatos, A.D.; Mylonakis, M.E. A cross-sectional study of Leishmania spp. infection in clinically healthy dogs with polymerase chain reaction and serology in Greece. Veterinary Parasitology, 109:19-27, 2002.

Lucena, D.T.; Oliveira, M.H.C.C.; Leal, M.C.A. Variação Mensal dos Flebotomíneos (DipteraPsychodidae) de Igarassu, PE. Cadernos Ômega, Universidade Federal Rural de PE. Série Biologia, 1(1):19-27, 1984.

Madeira, M.F.; Serra, C.M.B.; Uchoa, C.M.A.; Duarte, R.; Cruz, D.A.M.; Perdomo, C.C. Leishmaniose canina: avaliação sorológica de 310 cães na região de Itaipu, Rio de Janeiro. Cadernos de Saúde Pública, 16:56, 2000.

Madeira, M.F.; Uchôa, C.M.A.; Leal, C.A.; Silva, R.M.M.; Duarte, R.; Magalhães, C.M.; Serra, C.M.B. Leishmania (Viannia) braziliensis em cães naturalmente infectados. Revista da Sociedade Brasileira de Medicina Tropical de São Paulo, 36:551-555, 2003.

Marco, J.D.; Padilla, A.M.; Diosque, P.; Fernández, M.M.; Malchiodi, E.L.; Basombrío, M.A. Force of infection and evolution of lesions of canine tegumentary leishmaniasis in Northwestern Argentina. Memórias do Instituto Oswaldo Cruz, 96: 649-652, 2001.

Marquez, E.S.; Castro, E.A.; Nabut, L.B.; CostaRibeiro, M.C.V.; Araújo, L.D.C.T; Poubel, S.B.; Gonçalves, A.L.; Cruz, M.F.R.; Trad, A.P.M.E.S.; Dias, R.A.F.; Navarro, I.T.; Thomaz-Soccol, V. Cutaneous leishmaniosis in naturally infected dogs in Paraná, Brazil, and the epidemiological implications of Leishmania (Viannia) braziliensis detection in internal organs and intact skin. Veterinary Parasitology, 243:219-225, 2017.

Martins, L.; Alexandrino, A.; Guimarães, G. Detecção de DNA de Leishmania braziliensis em pacientes de Leishmaniose Tegumentar Americana. Revista de Saúde Pública, 44(3): 571-574, 2010.

Membrive, N.A.; Rodrigues, G.; Gualda, K.P.; Bernal, M.V.Z.; Oliveira, D.M.; Lonardoni, M.V.C.; Teodoro, U.; Teixeira, J.J.V.; Silveira, T.G.V. Environmental and animal characteristics as factors associated with American cutaneous leishmaniasis in rural locations with presence of dogs, Brazil. PLOS ONE, 7(11): e47050, 2012.
Mendonça, S.C.; Souza, W.J.; Nunes, M.P.; Marzochi, M.C.; Coutinho, S.G. Indirect immunofluorescence test in New World leishmaniasis: serological and clinical relationship. Memórias do Instituto Oswaldo Cruz, 83:347-355, 1988.

Reithinger, R.; Davies, C.R. American cutaneous leishmaniasis in domestic dogs: an example of the use of the polymerase chain reaction for mass screening in epidemiological studies. Transactions of the Royal Society Tropical Medicine Hygene, 96:123-126, 2002.

Reithinger, R.; Espinoza, J.C.; Davies, C.R. The transmission dynamics of canine American cutaneous leishmaniasis I Huanuco, Peru. The American Journal of Tropical Medicine and Hygiene, 69:473-480, 2003.

Santos, G.; Sanavria, A.; Marzochi, M.C.A.; Santos, E.G.O.B.; Silva, V.L.; Pacheco, R.S.; Mouta-Confort, E.; Espíndola, C.B.; Souza, M.B.; Ponte, C.S.; Conceição, N.F.; Andrade, M.V. Prevalência da infecção canina em áreas endêmicas de leishmaniose tegumentar americana, do município de Paracambi, Estado do Rio de Janeiro, no período entre 1992 e 1993. Revista da Sociedade Brasileira de Medicina Tropical, 38:161166, 2005.

Santaella, J.; Ocampo, C.B.; Saravia, N.G.; Méndez, F.; Góngora, R.; Gomez, M.A.; Munstermann, L.E.; Quinnell, R.J. Leishmania (Viannia) infection in the domestic dog in Chaparral, Colombia. The American Journal of Tropical Medicine and Hygiene, 84: 674-680, 2011.

Silva, A.P.O; Miranda, D.E.O.; Santos, M.A.B.; Guerra, N.R.; Marques, S.R.; Alves, L.C.; Ramos, R.A.N.; Carvalho. G.A. Phlebotomines in an area endemic for American cutaneous leishmaniasis in northeastern coast of Brazil. Brazilian Journal of Veterinary Parasitology, 26(3):280-284, 2017.

Silva-Filho, M.F.; Tamekuni, K.; Toledo, R.S.; Dias, R.C.F.; Lopis-Mori1, F.M.R.; MitsukaBreganó, R.; Thomaz-Soccol, V.; Luis Garcia, J.L.; Freire, R..; Vidotto, O.; Navarro, I.T. Infection by Toxoplasma gondii and Leishmania spp. in humans and dogs from rural settlements in Northern Paraná State, Brazil. Semina: Ciências Agrárias, 33 (supl. 2): 3251-3264, 2012. 
Velasquez, L.G.; Membrive, N.; Membrive, U.; Rodrigues, G.; Reis, N.; Lonardoni, M.V.C.; Teodoro, U.; Tessmann, I.P.B.; Silveira, T.G.V. PCR in the investigation of canine American tegumentary leishmaniasis in northwestern Paraná State, Brazil. Cadernos de Saúde Pública, 22:571-578, 2006.

Vélez, I.D., Carrillo, L.M.; López, L., Rodríguez, E.; Robledo, S.M. An epidemic outbreak of canine cutaneous leishmaniasis in Colombia caused by Leishmania braziliensis and Leishmania panamensis. The American Journal of Tropical Medicine and Hygiene, 86(5):807-811, 2012.

Zanzarini, P.D.; Santos, D.R.; Santos, A.R. Leishmaniose tegumentar americana canina em município do norte do estado do Paraná. Cadernos de Saúde Pública, 21:1957-1961, 2005. 